\title{
Reproductive biology of Isurus oxyrinchus captured by the south Brazilian surface longline commercial fleet in the Southwest Atlantic Ocean, with data on CPUE and size distribution by sex
}

\author{
Gabriel Canani \\ Programa de Pós-graduação em Oceanografia Biológica, Instituto de Oceanografia, Universidade \\ Federal de Rio Grande, Avenida Itália, Km 8, Campus Carreiros, \\ Rio Grande, RS, Brasil, CEP 96203-900 \\ Maria Cristina Oddone* \\ Instituto de Ciências Biológicas, Setor de Morfologia, Universidade Federal de Rio Grande, \\ Avenida Itália, $\mathrm{Km} 8$, Campus Carreiros, \\ Rio Grande, RS, Brasil, CEP 96203-900 \\ *mcoddone@gmail.com
}

Canani, G. and Oddone, M.C. 2020. Reproductive biology of Isurus oxyrinchus captured by the south Brazilian surface longline commercial fleet in the Southwest Atlantic Ocean, with data on CPUE and size distribution by sex. J. Northw. Atl. Fish. Sci., 51: 105-116. https://doi.org/10.2960/J.v51.m724

\begin{abstract}
Knowledge of reproductive parameters is necessary to efficiently evaluate and manage fishing stocks. Shortfin Mako constitutes the second most captured shark by the longline hook fleet situated in Rio Grande, RS, Brazil. However, little is known about the reproductive traits or abundance of this species in the Southwest Atlantic. Here we report on size and maturity, from 37 males and 46 females sampled in scientific cruises between September 1996 and August 1999, and commercial fishing cruises between December 2014 and September 2016, in South Brazilian Waters and Northern Uruguayan Waters. First results for male maturity are presented. Males between 119.0 and $270.0 \mathrm{~cm}$ TL (Total length) including all maturity stages were captured; eighteen adults, nine juveniles and ten immature individuals. The observed size at maturity was between 137 and $182.0 \mathrm{~cm}$ TL. Maturity ogive analyses indicate an L50 of $180.1 \mathrm{~cm} \mathrm{TL}$ and L90 was $199.0 \mathrm{~cm}$ TL. Juveniles presented testicle weight between 84.4 and $92.2 \mathrm{~g}$, while adult weights were between 158.4 and $352.8 \mathrm{~g}$. Only immature females were captured $(n=46$ ), with sizes between 104.0 and $230.0 \mathrm{~cm} \mathrm{TL}$, and oviduct width between 4.1 and $7.15 \mathrm{~mm}$. The CPUE varied between 0.57 and 2.38 individuals per thousand hooks. Overall sex ratio slightly favored females, 1.24:1 (F|M).
\end{abstract}

Key words: South Brazil, reproductive biology, population structure, pelagic shark

\section{Introduction}

Reproductive parameters such as size or age at maturity are important for evaluating recruitment of sharks, and therefore evaluating fisheries and population status (Holden, 1974; Cortés et al., 2012). Acquiring information on sexual maturity can inform biological and ecological traits of the species. These traits may be even sex biased, given that sexual dimorphism and site segregation are common in sharks (Francis and Duffy 2005; Semba et al., 2011, Tsai et al., 2014). Tsai et al. (2014) indicated from a fishery management perspective that ignoring the differences in population growth rates between sexes, as well as in social structure i.e., unsexed stock management can underestimate population decline risks.

The family Lamnidae ("mackerel" sharks, order Lamniformes), includes the genera Carcharodon Smith, 1838, Lamna Cuvier, 1816, and Isurus Rafinesque 1810 (Compagno, 2005). In regard to the Shortfin Mako Isurus oxyrinchus Rafinesque, 1810, Shortfin Mako is endothermic, being able to maintain higher temperatures than the surrounding water with counter-current vascular heat exchange (Carey and Teal, 1969). This physiological trait facilitates a high movement and migratory capacity. The species is oceanic, semipelagic and littoral and distribution 
is circumglobal in temperate and tropical seas. In the Western Atlantic, Shortfin Mako occurs from Newfoundland (Canada) (Casey and Kohler, 1992) to northern Argentina (Compagno, 1984; 1990).

In the South and Central Atlantic waters, Shortfin Mako is the second most captured shark in longline fisheries (Barreto et al., 2016a). Having such a wide range exposes the Shortfin Mako to a large number of fishing fleets, the longline hook fishery being the primary threat (Cortés et al., 2010, Barreto et al., 2016a). Barreto et al., (2016a) reviewed historical catches by the longline fishery fleets in the South Atlantic Ocean, identifying three main phases. The first (1979-1997), a period with low effort employing multifilament lines targeting tunas was characterized by increasing shark catches as the fishery developed. The second phase (1998-2007) was a period of expansion and monofilament line was introduced targeting sharks as well as tunas, resulting in a decline of $55 \%$ in Shortfin Mako catches. Finally, during a third phase, shark catches stabilized at a lower level. Mourato et al., (2011) found high percentages of captures of the Shortfin Mako, regardless of the targeted species in longline fisheries off the southeastern coast of Brazil. Shortfin Mako represent $2.6 \%$ of total catches in fisheries targeting blue sharks, Prionace glauca (Linnaeus 1758), 3.0\% in fisheries for swordfish Xiphias gladius Linnaeus, 1758 and 4.4\% in multi species fisheries (Mourato et al., 2011). The overall declining trend of the Shortfin Mako captures could suggest a depletion of the stock, and thus an endangered status to the species (Barreto et al., 2016a), currently categorized by the IUCN as "Endangered" both globally and regionally, in the Atlantic (Rigby et al., 2018).

With respect to reproduction strategies, oophagy was documented in all members of the Lamniformes, including the Shortfin Mako (Gilmore, 1993; Mollet et al., 2000; Joung and Hsu, 2005). Following initial yolk-sac nutrition, oophagy, a type of matrotrophic viviparity occurs where intrauterine embryos ingest unfertilized eggs continuously produced by the mother (Hamlett and Koob, 1999). As the embryos consume and store the yolk present in the ova, they develop an expanded abdomen called "cardiac" or "yolk" stomach, characteristic and exclusive of the Lamniformes (Gilmore 1993, 2005; Mollet et al., 2000; Wyffels, 2009). Approximately two months before birth, the embryos consume the yolk and develop livers proportionally identical to the adults in relation to their weight (Gilmore, 1993, 2005; Mollet et al., 2000; Joung and Hsu, 2005). Among oophagic species, the adelphophagy, embryophagy or "intrauterine cannibalism" has been recorded in I. oxyrinchus and Carcharias taurus Rafinesque, 1810 (Mollet et al., 2000; Gilmore, 2005; Joung and Hsu, 2005).
Shortfin Mako size at sexual maturity ranges between 156 and $210 \mathrm{~cm}$ for males and between 256 and $285 \mathrm{~cm}$ for females, with great variation among regions and studies (Mollet et al., 2000; Joung and Hsu 2005; Semba et al., 2011, see Table 3 for details). Regardless of the growing amount of information on biology and reproductive parameters of the Shortfin Mako in the last 30 years, there is still a considerable lack of information about this species, as for most of Lamniformes (Gilmore 1993, 2005; Mollet et al., 2000). Moreover, size at maturity estimates for male Shortfin Mako were not available for the South West Atlantic.

Stevens (2008) stated that, in spite of being commonly captured, the biology of this species is still not well understood. The economical and ecological importance of the species, the apparent declining populations trend, lack of reproductive studies in the Southwest Atlantic, discrepancies among studies and differences among populations of the Shortfin Mako highlight the need to acquire fishing and reproductive biology information for this species. The aim of this study was to study the reproductive biology of Isurus oxyrinchus captured by the south Brazilian surface longline commercial fleet in the Southwest Atlantic Ocean, and to provide data on CPUE and size distribution by sex. Here, we present population structure data, average size per season sampled and reproductive parameters.

\section{Material and methods}

\section{Study Area}

The fishing cruises were carried out in the area situated in the Southwest Atlantic Ocean, between latitude $29^{\circ}$ and $36^{\circ} \mathrm{S}$, and longitude $47^{\circ}$ and $53^{\circ} \mathrm{W}$ (Fig. 1), in depths between 140 and $2200 \mathrm{~m}$. This area corresponds to the southernmost Brazilian states; Santa Catarina and Rio Grande do Sul, respectively and including the northernmost Uruguayan waters. The main currents acting on the surface waters are the Brazil Current, which flows southward, characterized by warm and oligotrophic waters, and the Malvinas (Falklands) Current, flowing northward, composed by Antarctic Circumpolar Waters which are mixed with coastal waters coming from the La Plata River, these mixed waters are characterized by cold and nutrient-rich waters. These two currents with opposite flows meet each other, forming the South Atlantic Subtropical Convergence (Garcia, 1997).

\section{Sample collection}

Samples were collected during six trips aboard a $22 \mathrm{~m}$ length steel longliner, fishing in the south Brazilian inner 
and outer shelves from December 2014 to September 2016 (Table 1). An additional specimen was sampled during a single fish landing event in the port of the city of Rio Grande. Hooks were fixed using a steel line, appropriate for capturing large sharks and swordfishes. The usual set consisted of 800 hooks, varying between 600 and 1050 hooks. Also, data from scientific longline cruises obtained in the same area between 1996 and 1999 by the project ARGOS (conducted by the former Laboratório de Elasmobrânquios e Aves Marinhas, Instituto de Oceanografia, Universidade Federal do Rio Grande) were also included (Fig.1). Catch per unit effort (CPUE) was calculated only for fisheries cruises, using 800 hooks per set for effort calculation. The total effort per cruise was not available for the scientific cruises.
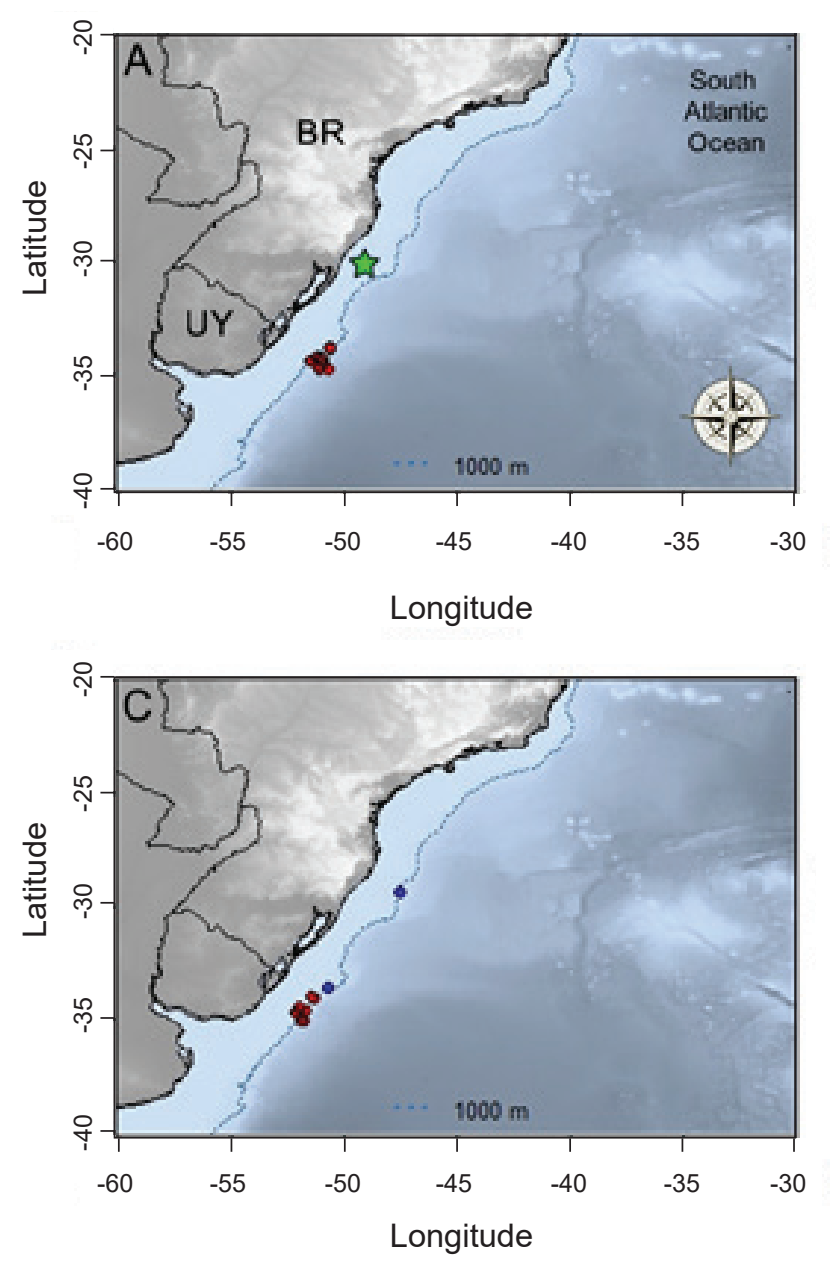

\section{Biological and biometric sampling}

The external measurements were taken at sea, as the fish were brought on board. For each specimen, total length (TL), fork length (FL) and interdorsal space (IS) were recorded to the nearest $\mathrm{cm}$ below. For males, the postcloacal length of the clasper (CL) was measured from the clasper distal end to the posterior margin of the cloaca opening, according to Maia et al. (2007). Clasper calcification was recorded manually, with the claspers being classified as 'rigid' or 'flexible' for maturity assessment. Due to access difficulties in biological sampling for reproduction assessment intrinsic of this species (also reported by Maia et al., 2007, and Barreto et al., 2016b), the testicles of seven specimens were weighed. Testicle weight $(\mathrm{g})$ (including the epigonal
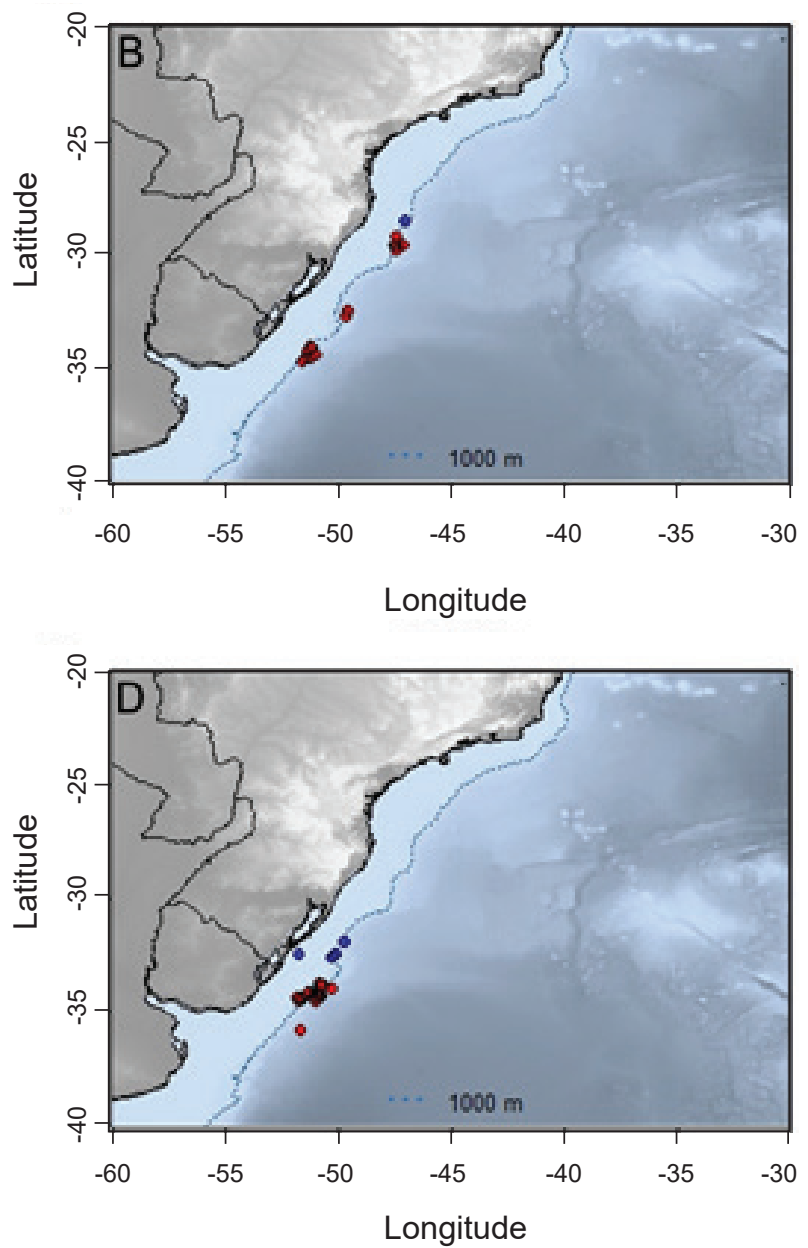

Fig. 1. The study area, the Southwestern Atlantic Ocean, off southern Brazil (BR) and northern Uruguay (UY), where the samples of the Shortfin Mako Isurus oxyrinchus were collected. Red dots represent the longline fisheries captures (2014-2016), blue dots represent scientific cruises (longline fishing gear), carried out between 1996 and 1998. Star symbol represents the nursery proposed by Vooren et al. (2005). Depth isobath: $1000 \mathrm{~m}$. A: summer, B: autumn, C: winter, D: spring. 
organ) was recorded using an electric scale $(0.1 \mathrm{~g}$ precision) considering both testicles together. Also, uterus width was recorded for 12 females, being measured in the middle region of the oviduct.

\section{Analysis and statistics}

To assess sexual maturity, criteria proposed by Semba et al. (2011) for the shortfin mako shark were applied. To determine maturity in males, the calcification and mobility of the clasper were examined, and maturity was as follows: stage 1-immature (not calcified claspers); stage 2-juvenile (semi-rigid and calcified claspers with low mobility (clasper rotation forward along the caudal-cephalic body axis) and no spurs) and stage 3-adult (calcified, high mobility, spurs).

The normality of TL and CL measurements was tested using the Shapiro-Wilk test. Morphometrics were analyzed by plotting all measurements using linear regression (Pratt and Casey, 1983), to observe the relationship between total length and clasper length. The sex ratio was established as the ratio of total females to total males. A statistical $\mathrm{X}^{2}$ test was applied to test differences between sexes. The logistic model $Y=[1+\exp \{-(\mathrm{a}+\mathrm{bX}\}]-1$ (sensu Mollet et al., 2000) was fitted to the relationship between the percentage of mature males $(\mathrm{Y})$ and TL classes of $10 \mathrm{~cm}(\mathrm{X})$, and $a$ and $b$ are parameters estimated by a generalized linear model (GLM) with a binomial distribution. Statistical analyses and figures were performed using the program R, ver. 3.2.2 (R Development Core Team, 2019).

\section{Ethical considerations}

For the collection of specimens of I. oxyrinchus on board the fishing vessels, permission of the Instituto Chico Mendes de Conservação da Biodiversidade (ICMBio) and Sistema de Autorização e Informação em Biodiversidade (SISBIO) was requested, license number 45279-1. This research is part of the research project "The biology and conservation of shark populations in the extreme south of Brazil" registered at the Universidade Federal do Rio Grande under process number 814440/2014, with awareness of the Ethics Committee in Animal Use (Comissão de Ética Em Uso Animal - CEUA of the same university. No experimental work was undertaken with the specimens collected.

Table 1. Data on the overall commercial fishing cruises (between December 2014 and September 2016 by the sea-surface longline fleet based in south Brazil) and scientific fishing cruises (ARGOS, between September 1996 and August 1999) conducted off southern Brazil, Southwestern Atlantic Ocean, where samples of the Shortfin Mako Isurus oxyrinchus were obtained. Fishing sets were standardized in 800 hooks.

\begin{tabular}{|c|c|c|c|c|c|c|}
\hline Cruise & Season & Area & $\begin{array}{l}\text { Days at } \\
\text { sea }\end{array}$ & $\begin{array}{l}\text { Fishing } \\
\text { sets }\end{array}$ & Mean depth (m) & Mean Temperature \\
\hline November/December 2014 & Summer & $\begin{array}{l}33-34^{\circ} \mathrm{S} \\
50-51^{\circ} \mathrm{W}\end{array}$ & 19 & 11 & $2030(1200-3500)$ & $23.9^{\circ} \mathrm{C}(21.2-23.9)$ \\
\hline March 2015 & Autumn & $\begin{array}{l}29-32^{\circ} \mathrm{S} \\
49-47^{\circ} \mathrm{W}\end{array}$ & 11 & 5 & $1800(1525-2000)$ & $25.1^{\circ} \mathrm{C}(24.8-26.2)$ \\
\hline June 2015 & Winter & $\begin{array}{l}33-35^{\circ} \mathrm{S} \\
51-52^{\circ} \mathrm{W}\end{array}$ & 13 & 9 & $205(150-438)$ & $20.6^{\circ} \mathrm{C}(16.8-21.1)$ \\
\hline November 2015 & Spring & $\begin{array}{l}34-35^{\circ} \mathrm{S} \\
50-51^{\circ} \mathrm{W}\end{array}$ & 17 & 9 & $1300(144-2000)$ & $20.4^{\circ} \mathrm{C}(19.2-22)$ \\
\hline March 2016 & Autumn & $\begin{array}{l}29-34^{\circ} \mathrm{S} \\
47-51^{\circ} \mathrm{W}\end{array}$ & 15 & 9 & $1170(487-1523)$ & $24.9^{\circ} \mathrm{C}(24.2-25.3)$ \\
\hline September 2016 & Spring & $\begin{array}{l}33-34^{\circ} \mathrm{S} \\
50^{\circ} \mathrm{W}\end{array}$ & 13 & 10 & $1288(1000-1500)$ & - \\
\hline September $1996^{*}$ & Spring & $\begin{array}{l}32^{\circ} \mathrm{S} \\
50^{\circ} \mathrm{W}\end{array}$ & 7 & 6 & $530(200-960)$ & - \\
\hline November $1996.2 *$ & Spring & $\begin{array}{l}31-34^{\circ} \mathrm{S} \\
49-51^{\circ} \mathrm{W}\end{array}$ & 8 & 7 & $800(400-1100)$ & $21^{\circ} \mathrm{C}$ \\
\hline April 1998.2* & Autumn & $\begin{array}{l}28^{\circ} \mathrm{S} \\
47^{\circ} \mathrm{W}\end{array}$ & 9 & 6 & $570(376-760)$ & $26^{\circ} \mathrm{C}$ \\
\hline August 1999.1* & Winter & $\begin{array}{l}29-33^{\circ} \mathrm{S} \\
47-50^{\circ} \mathrm{W}\end{array}$ & 10 & 6 & $1090(667-1500)$ & - \\
\hline
\end{tabular}




\section{Results}

\section{Reproductive biology}

The sample analyzed (Table 2) was composed of immature males (stage $1, n=10$ ), with (CL) ranging from 6.0 to $12.3 \mathrm{~cm}$ juveniles (stage $2, n=9$ ), with (CL) from 9.5 to $22 \mathrm{~cm}$ and adults (stage $3, n=18$ ) showing a CL range between 18.5 and $35.4 \mathrm{~cm}$. The development of the clasper correlated with TL, exhibited three distinct phases. The first, with slow clasper growth and samples between 119.0 and $162.0 \mathrm{~cm}$ TL, followed by a rapid growth between 137.0 and $182.0 \mathrm{~cm}$ TL, and when maturity is reached, showing a slow growth once again (Fig. 2). The observed size (TL) at first maturity in the sample corresponded to the range 168.0-182.0 cm TL (TL of the smallest mature individual and largest immature individual, respectively). Regarding the maturity ogive analysis, TL at 50\% maturity was found to lay at $180.1 \mathrm{~cm}$, and $90 \%$ maturity at $199.0 \mathrm{~cm}$ (Fig. 3). Testicles weight ranged from 84.4 to $92.2 \mathrm{~g}$ in males stage $2(n=3)$ and from 158.4 to $352.8 \mathrm{~g}$ in adults $(n=4)$.

A total of 46 immature females were captured ranging from 104.0 to $230.0 \mathrm{~cm}$ TL. There was only one stage-2 (204.0 cm TL), and no stage-3 females in record. Eleven specimens had their oviduct width measured, presenting values between 4.1 and $7.15 \mathrm{~mm}$.

\section{Population structure}

A total of 83 individuals were captured and measured over the six fishing cruises and four scientific cruises (Table 2), with number of individuals varying between 1 and 26 per cruise. The TL range for the total sample varied from 104.0 to $270.0 \mathrm{~cm}$ (Fig. 4), with a mean of $165.7 \mathrm{~cm}$. Altogether, 37 males were captured, TL ranging between 119.0 and $270.0 \mathrm{~cm}$, with a mean of $177 \mathrm{~cm}$, while the 46 females captured had TL values between 104.0 and $230.0 \mathrm{~cm}$, with a mean of 156.6. The smallest individual was 104.0 $\mathrm{TL}$ female, captured in July 2015 , at $20.8^{\circ} \mathrm{C}$ and $150 \mathrm{~m}$ depth, while the larger individual was a $270.0 \mathrm{~cm}$ male, captured in March 2015 at $24.9^{\circ} \mathrm{C}$ surface temperature and $2000 \mathrm{~m}$ depth.

In relation to the CPUE, the highest value was recorded in the Spring sets, which presented 2.83 individuals per 1000 hooks, followed by Winter (1.67), Autumn (0.74) and Summer (0.57). The mean TL was smaller in the Winter sets (134), increasing in Spring (163), Summer (191) and Autumn (214). The largest individuals were captured in the March 2015 Cruise (Autumn), with the samples varying between 177.0 and $270.0 \mathrm{~cm}$, and

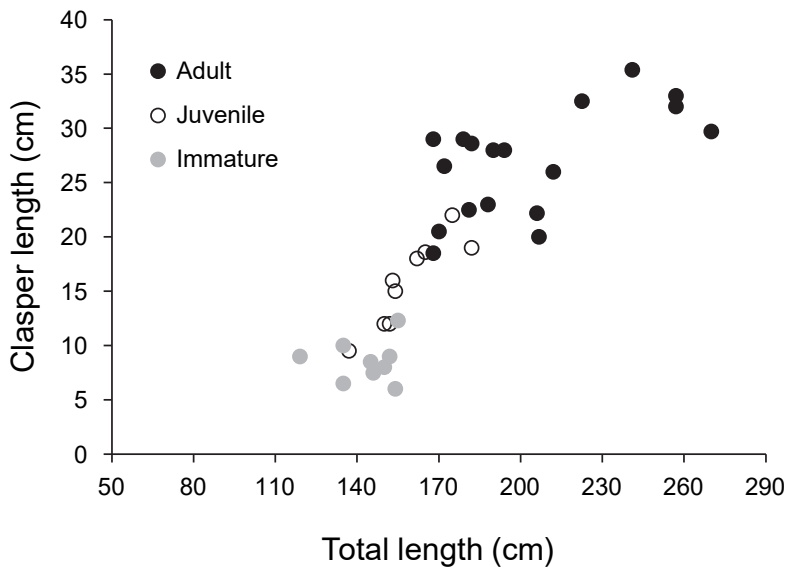

Fig. 2. Relationship between total length $(\mathrm{cm})$ and clasper length $(\mathrm{cm})$ for the maturity stages considered; immature (grey circle symbols), juvenile (empty circle symbols) and adult individuals (black circle symbols) of the Shortfin Mako Isurus oxyrinchus captured by pelagic longline vessels off southern Brazil and northern Uruguay, Southwestern Atlantic Ocean.

composed almost exclusively by males larger than $240.0 \mathrm{~cm}$, with the exception of a $177.0 \mathrm{~cm}$ TL female, whilst the smaller individuals were recorded in the June 2015 cruise (Winter), with captures composed mostly by females smaller than $160.0 \mathrm{~cm}$. The CPUE by season and maturity stage is presented in Figs. 5, 6 and 7. The overall sex ratio, 1.24:1, favoured females, was statistically significant $\left(\chi^{2}=0.38, p=0.53\right)$, and was highly variable among seasons. The higher $\mathrm{F}: \mathrm{M}$ ratio was registered in the winter sets $(6: 1)$, decreasing in Spring (1.12:1), and favouring males in Autumn (0.8:1) and Summer (0.25:1).

\section{Discussion}

Constituting the first estimate for the SW Atlantic Male TL at $50 \%$ maturity was estimated at $180 \mathrm{~cm}$. For other areas of the Atlantic, Stevens (1983) and Maia et al. (2007) had provided estimations for the NW and NE Atlantic, respectively. Our estimate falls within the range of values observed elsewhere (from 150 to $180 \mathrm{~cm}$ TL) (Table 3). Our ogive analysis, although based on a relatively small sample of immature juveniles (19 in all), showed the expected sigmoidal curve and size at maturity for males, congruent with other studies. Compared to other clasper length-TL studies, immature males in the range of 50-100 $\mathrm{cm}$ are missing from the present study (see for instance, Conde-Moreno and Galván-Magaña, 2007; Semba et al., 2011). As only immature females were captured, maturity estimates are not available in 
Table 2. Data on the captures of the Shortfin Mako Isurus oxyrinchus by longline commercial fisheries cruises (between December 2014 and September 2016 by the sea-surface longline fleet off southern Brazil and northern Uruguay) and scientific fishing cruises* (between September 1996 and August 1999) in the Southwestern Atlantic Ocean. Fishing sets were standardized in 800 hooks.

\begin{tabular}{|c|c|c|c|c|c|c|}
\hline Cruise & Season & Set & Depth & Sex ratio(Males|Females) & Mean TL $\widehat{o}$ & Mean TL $q$ \\
\hline December 2014 & Summer & 4 & 1500 & $(1 \mid 0)$ & 154 & - \\
\hline December 2014 & Summer & 5 & 2000 & $(1 \mid 0)$ & 206 & - \\
\hline December 2014 & Summer & 6 & 1200 & $(1 \mid 1)$ & 165 & 224 \\
\hline December 2014 & Summer & 7 & 1200 & $(1 \mid 0)$ & 206.7 & - \\
\hline March 2015 & Autumn & 1 & 2000 & $(1 \mid 0)$ & 270 & - \\
\hline March 2015 & Autumn & 2 & 1900 & $(1 \mid 1)$ & 241 & 177 \\
\hline March 2015 & Autumn & 3 & 1525 & $(1 \mid 0)$ & 257 & - \\
\hline June 2015 & Winter & 8 & 438 & $(0 \mid 1)$ & - & 107 \\
\hline June 2015 & Winter & 9 & 250 & $(2 \mid 9)$ & $147(119-175)$ & $130(107-185.5)$ \\
\hline November 2015 & Spring & 1 & $2000-800$ & $(4 \mid 1)$ & 198.6(190-212) & 230 \\
\hline November 2015 & Spring & 3 & 1800 & $(0 \mid 2)$ & - & 181(164-198) \\
\hline November 2015 & Spring & 4 & 967 & $(2 \mid 1)$ & $160.5(153-168)$ & 174 \\
\hline November 2015 & Spring & 5 & 145 & $(0 \mid 2)$ & - & $194.5(180-209)$ \\
\hline November 2015 & Spring & 6 & 2000 & $(1 \mid 2)$ & 154 & $176.5(142-211)$ \\
\hline November 2015 & Spring & 8 & 1422 & $(1 \mid 2)$ & 222.5 & 122 \\
\hline March 2016 & Autumn & 5 & 1429 & $(0 \mid 1)$ & - & 186 \\
\hline March 2016 & Autumn & 6 & $1143-990$ & $(1 \mid 1)$ & 188 & 182 \\
\hline March 2016 & Autumn & 8 & 1900 & $(1 \mid 0)$ & 257 & \\
\hline September 2016 & Spring & 3 & 1500 & $(2 \mid 5)$ & 175 & 127.8 \\
\hline September 2016 & Spring & 4 & 1500 & $(2 \mid 3)$ & 148.5 & 139 \\
\hline September 2016 & Spring & 5 & 1500 & $(0 \mid 1)$ & - & 186 \\
\hline September 2016 & Spring & 6 & 1500 & $(1 \mid 1)$ & 170 & 152 \\
\hline September 2016 & Spring & 8 & 1500 & $(1 \mid 0)$ & 146 & - \\
\hline September 2016 & Spring & 9 & 1000 & $(5 \mid 2)$ & 160.2 & 132.5 \\
\hline September 2016 & Spring & 10 & 1000 & $(2 \mid 1)$ & 165.5 & 143 \\
\hline September $96^{*}$ & Spring & 1 & 510 & $(0 \mid 1)$ & - & 164 \\
\hline September $96^{*}$ & Spring & 2 & 865 & $(0 \mid 1)$ & - & 204 \\
\hline November $96^{*}$ & Spring & 1 & 1000 & $(3 \mid 3)$ & $152.6(135-168)$ & $167(155-191)$ \\
\hline November $96^{*}$ & Spring & 6 & 900 & $(2 \mid 0)$ & $143.5(137-150)$ & - \\
\hline November $96^{*}$ & Spring & 7 & 1100 & $(0 \mid 2)$ & $184.5(152-217)$ & - \\
\hline April 98* & Autumn & 3 & 376 & $(0 \mid 1)$ & - & 169 \\
\hline August 99* & Winter & 2 & 667 & $(0 \mid 1)$ & - & 160 \\
\hline August 99* & Winter & 6 & 1300 & $(0 \mid 1)$ & - & 126.5 \\
\hline
\end{tabular}

this study. Given the effort concentrated in the same area, close to the Brazil-Uruguay Economic Exclusive Zone southernmost border, our data suggests size segregated groups, varying seasonally, with larger individuals concentrating northwards, in warmer waters and immature and juveniles migrating southwards as they grow.
Sampling oceanic and pelagic sharks is an expensive and difficult task, requiring many resources and structure, rarely allowing scientific cruises to be undertaken, thus leaving the assessment of their biological traits to fisherydependent means (Baum et al., 2003, Barreto et al., 2016a). In the specific case of the Shortfin Mako, access 


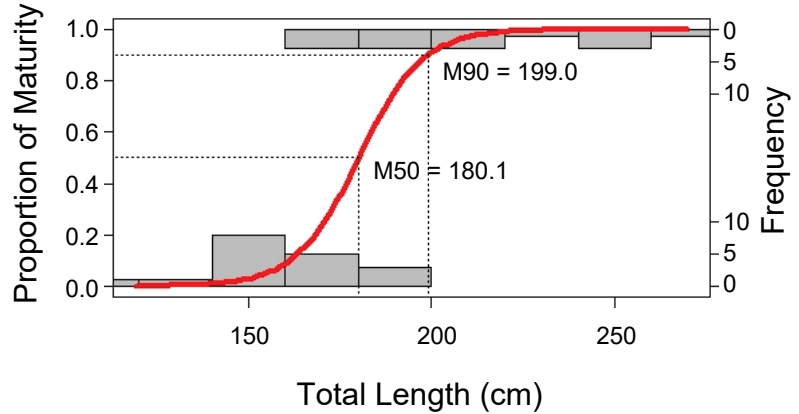

Fig. 3. Maturity ogive for male Shortfin Mako Isurus oxyrinchus captured by pelagic longline vessels off southern Brazil and northern Uruguay, Southwestern Atlantic Ocean. The curve represents the proportion of mature males calculated in relation to total length classes of $10 \mathrm{~cm}$ (left $\mathrm{Y}$ axis). The histogram represents the frequency of individual's size classes in the sample (right $\mathrm{Y}$ axis). Site at $50 \%$ maturity (M50) and at 90\% maturity (M90) are indicated.

to fish for biological sampling is even more problematic. Its valuable meat may discourage commercial skippers from allowing sampling (Barreto et al., 2016b). Fisherydependent sampling tends to concentrate efforts in areas of aggregation of other target species, varying in depths and areas. However, these snapshots can yield important information.

In winter months, the fleet sets its fishing gear in southernmost waters less than $500 \mathrm{~m}$ depth, catching mostly immature females and eventually juvenile males, while in the summer, autumn and spring months, the fishing operations were conducted in waters deeper than $800 \mathrm{~m}$, catching mostly adult and juvenile males, and occasionally immature females. These trends in distribution may provide information on spatial distribution and abundance of genders and maturity classes. Our data indicates mainly juvenile and immature aggregations with occasional presence of adult males in Southern Brazil pelagic waters. Vooren et al. (2005) reported neonates and young-of-the-year captures by gillnet fishery between January and March, in shallow coastal waters ( 28 to $63 \mathrm{~m}$ depth) between 29 and $31^{\circ} \mathrm{S}$, classifying the area as a nursery in the summer. Costa et al. (2002), analyzing pregnant females captured between September and February by longline tuna fishing vessels, northwards, between $20-28^{\circ} \mathrm{S}$, concluded that the birth period in Southeastern Brazil occurs in Spring (October to December). Migratory capacity among young-of-the-year and neonates is reported by Maia et al., (2007), and may explain our pattern observed in capture sizes observed, with the individuals going southwards, to feeding areas.
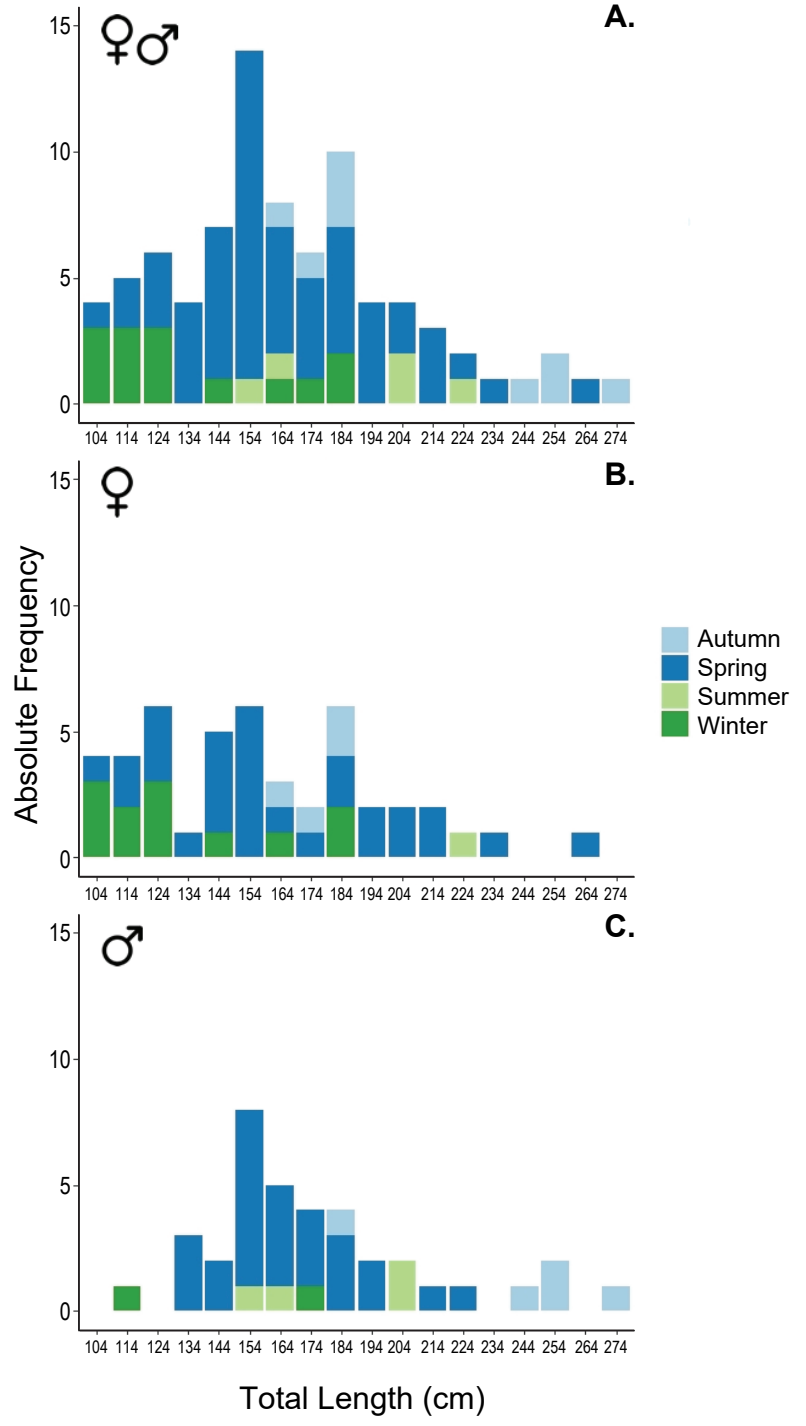

Fig. 4. Absolute frequency of individuals by total length class of $10 \mathrm{~cm}$, for total (A), female (B) and male (C) Shortfin Mako Isurus oxyrinchus captured by pelagic longline vessels off southern Brazil and northern Uruguay, Southwestern Atlantic Ocean, between December 2014 and September 2016.

The high migratory capacity and behavior of this species widely exposes its populations to a variety of fishing fleets and techniques, with young and neonates being captured by gillnet fisheries in shallower water closer to the continent and larger individuals being captured by more oceanic techniques such as longlines (Vooren et al., 2005; Costa et al, 2002; personal observations). This exposure makes the Shortfin Mako the second most captured shark in the South Atlantic, with immature individuals being the most exposed to fisheries (Barreto et al., 2016a). Tsai et al. (2014) showed by modeling sex- 

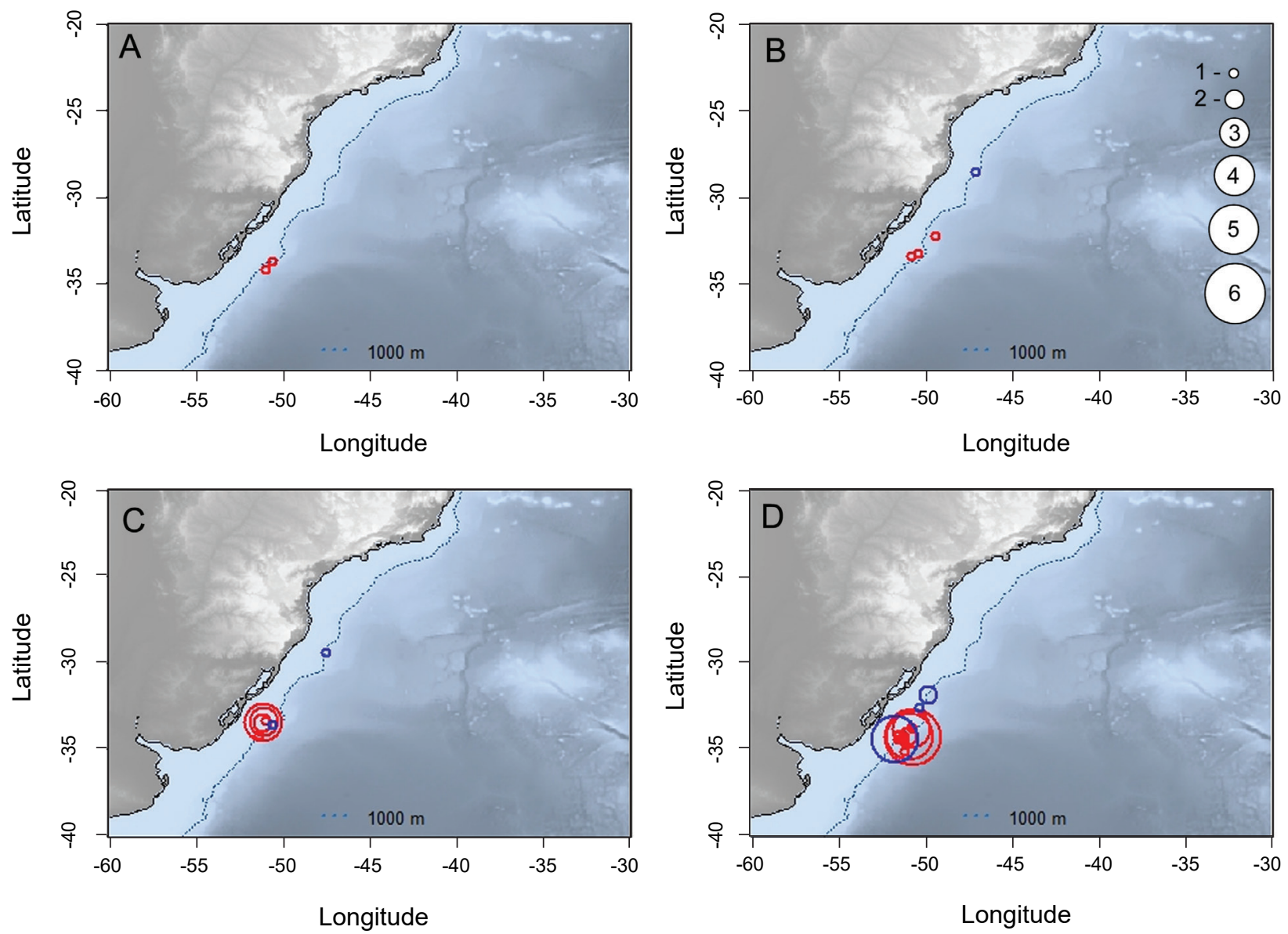

Fig. 5. Fishing sets and capture per unit effort for fisheries sampling of immature Shortfin Mako Isurus oxyrinchus captured by pelagic longline vessels off southern Brazil and northern Uruguay, Southwestern Atlantic Ocean, between December 2014 and September 2016 in South Brazil. The CPUE is represented by the size of circles symbols in individuals captured per set (blue $=$ Scientific cruises; red $=$ commercial fishing cruises). A: summer; B: autumn; $\mathbf{C}$ : winter; $\mathbf{D}$ : spring.

specific reproductive stocks that single-sex models could be biased, leading to wrong risk analyses and population estimates. Not only the capture of females (from all size classes) is detrimental to the population, captures of the male stock may lead to population depletion, depriving it from viable reproductive pairs (Tsai et al., 2014).

Genetic studies have suggested that the North and South Atlantic Shortfin Mako populations are not segregated, having some gene flow between them (Schrey and Heist, 2003). Nevertheless, female reproductive traits reviewed by Mollet et al. (2000) differ between hemispheres, which could be explained by habitat variation, with different food availability, for example. This situation signifies a discrete management approach, rather than to extrapolate trends and patterns from one hemisphere to the other.

Conservation decisions and laws have changed in Brazil in the last few years, as stated by Barreto et al. (2016a), with the prohibition on capturing Sphyrnids (any kind of landing, even as bycatch), among other threatened sharks. The changes in fishing laws have led to modifications of the fishing areas which had become shallower, and closer to nursery areas. These are important areas for fishery management, providing a greater contribution for recruitment than other areas (Beck et al., 2001). Monitoring captures in these areas is necessary. Immature individuals are not able to reproduce, and their capture may lead to future reduction of the reproductive stock and therefore reducing the population resilience, especially in slow growth and low fecundity species, as the Shortfin Mako. However, proper management should not focus on a given maturity stage. All stages should be subject of concern when conservation decisions are made. More detailed studies are necessary, quantifying not only number of individuals or biomass captured, but also length, age and maturity class distributions, allowing for a responsible and sustainable management of fisheries, conserving the stocks and the economic viability of fisheries. 

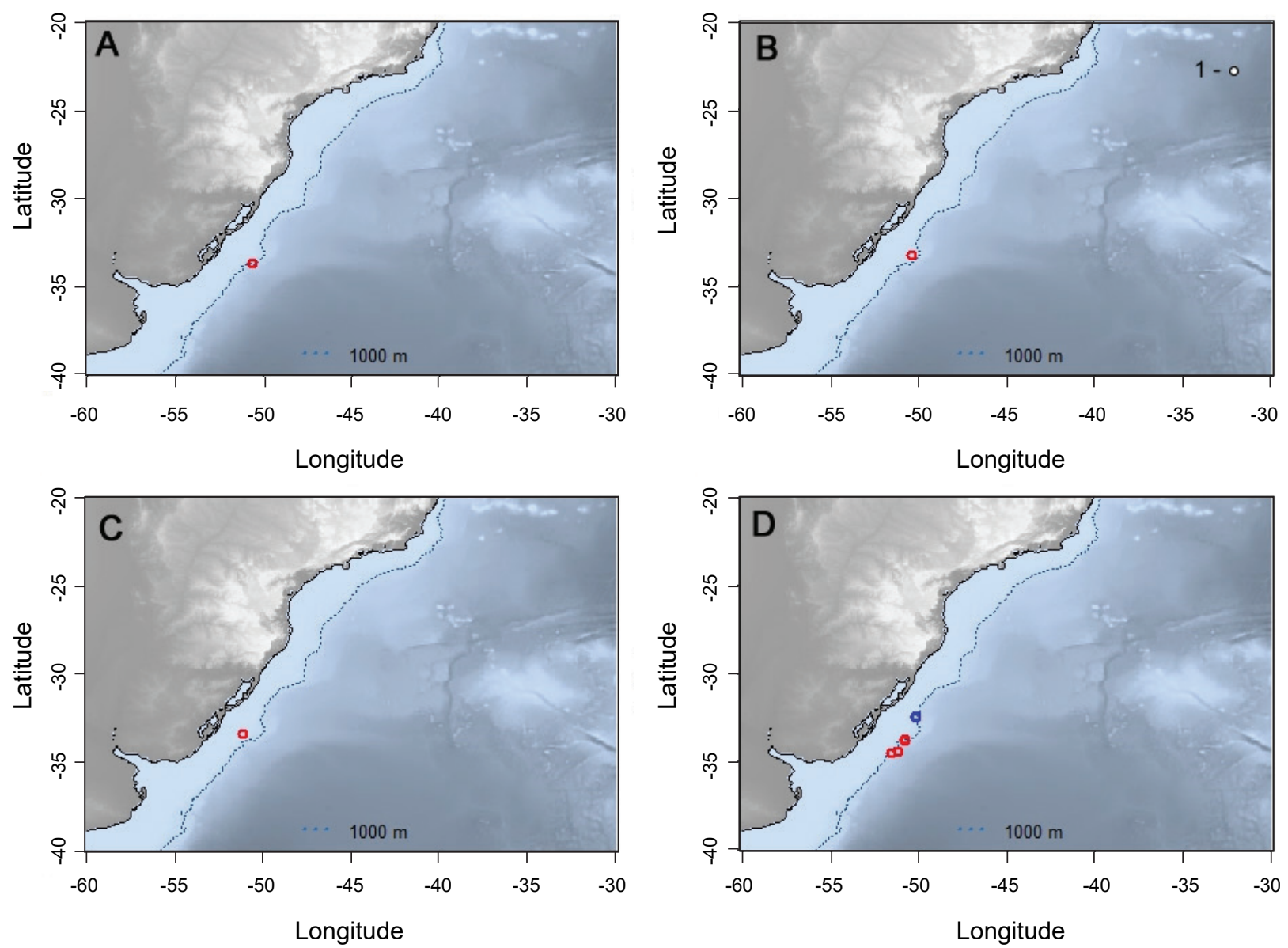

Fig. 6. Fishing sets and capture per unit effort for fisheries sampling of juvenile Shortfin Mako Isurus oxyrinchus captured by pelagic longline vessels off southern Brazil and northern Uruguay, Southwestern Atlantic Ocean, between December 2014 and September 2016 in South Brazil. The CPUE is represented by the size of circles symbols in individuals captured per set (blue $=$ Scientific cruises; red $=$ commercial fishing cruises). A: summer; B: autumn; $\mathbf{C}$ : winter; D: spring

Table 3. Total length at 50\% maturity (L50) for the Shortfin Mako Isurus oxyrinchus, in centimetres, reported by another studies and their location. Some studies provided $50 \%$ maturity estimates in terms of fork length (FL).

\begin{tabular}{llll}
\hline \hline Study & Male L50 & Female L50 & Location \\
\hline Conde-Moreno and Galván-Magaña (2007) & $158-207$ & - & Baja California - NE Pacific \\
Stevens (1985) & 195 & 280 & Florida - NW Atlantic \\
Mollet et al. (2000) & 180 & 280 & World Wide Review \\
Semba et al. (2011) & $156-173$ & $256-274$ & NW and Central Pacific \\
Maia et al. (2007) & 180 FL & $210-290$ FL & Portugal - NE Atlantic \\
Francis and Duffy (2005) & $180-185$ FL & $275-285$ FL & New Zealand - SW Pacific \\
Joung-Hsu (2005) & 210 & 178 & Taiwan - NE Pacific \\
This Study & 180 & - & Brazil - SW Atlantic \\
\hline
\end{tabular}



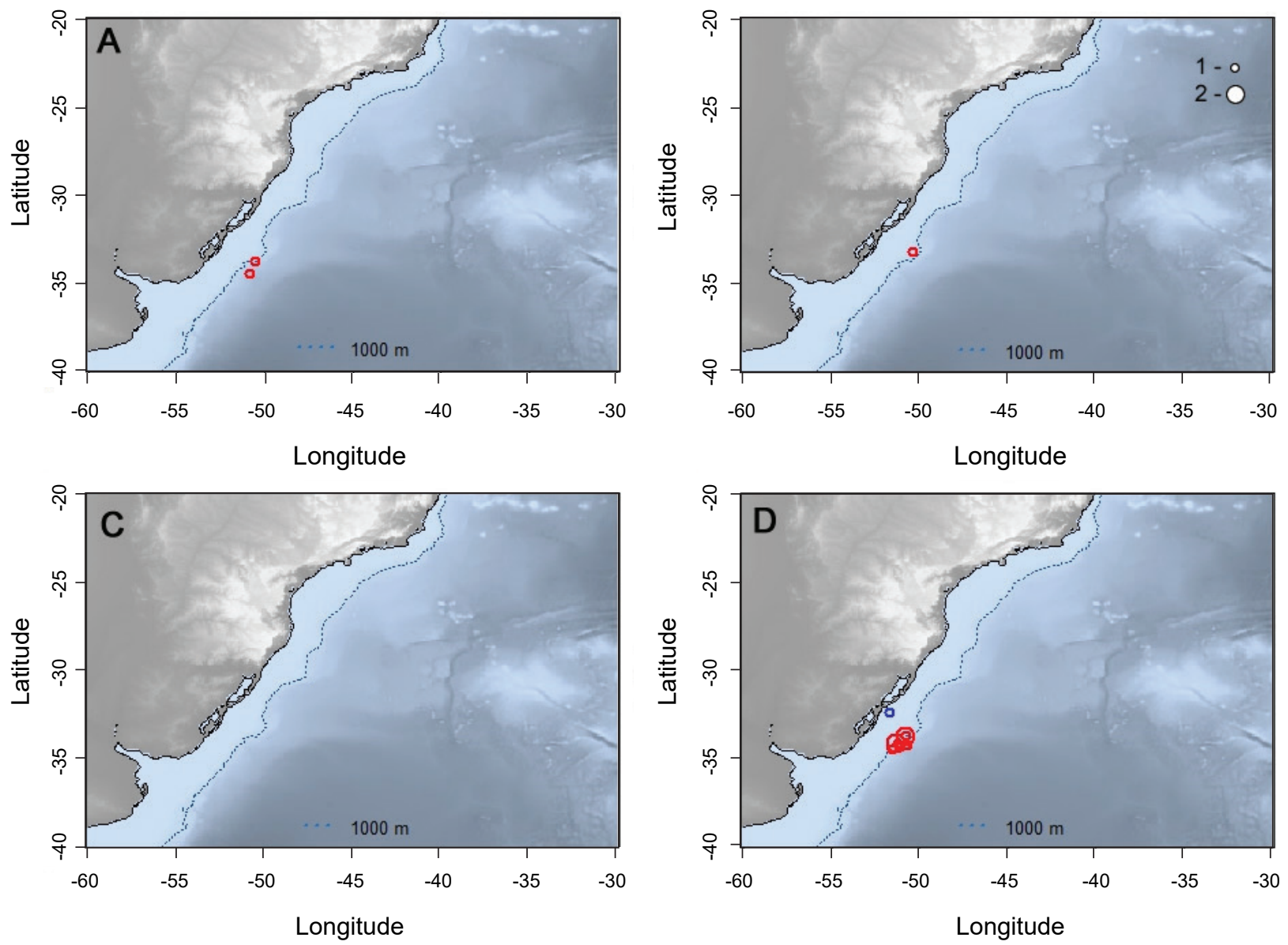

Fig. 7. Fishing sets and capture per unit effort for fisheries sampling of adult Shortfin Mako Isurus oxyrinchus captured by pelagic longline vessels off southern Brazil and northern Uruguay, Southwestern Atlantic Ocean, between December 2014 and September 2016 in South Brazil. The CPUE is represented by the size of circles symbols in individuals captured per set (blue $=$ Scientific cruises; red $=$ commercial fishing cruises). A: summer; B: autumn; C: winter; D: spring

\section{Acknowledgements}

We are very grateful to those who were involved in the realization of this research, particularly to the skippers for their receptivity and solicitude in receiving us on their boats. We also wish to thank the Instituto de Oceanografia/ FURG, for sharing the Project ARGOS data, and to Projeto Albatroz, specially to Augusto Costa, for the logistical support. This project was funded by the Coordenação de Aperfeiçoamento de Pessoal de Nível Superior (CAPES) with a master's degree scholarship.

\section{References}

Barreto, R. R., Ferretti, F., Flemming, J. M., Amorim, A. F., Andrade, H., Worm, B. and Lessa, R. 2016a. Trends in the exploitation of South Atlantic shark populations.
Conservation Biology, 30: 792-804. https://doi.org/10.1111/ cobi. 12663

Barreto R. R., Farias, W. K. T., Andrade, H., Santana, F. M. and Lessa, R. 2016b. Age, growth and spatial distribution of the life stages of the shortfin mako, Isurus oxyrinchus (Rafinesque, 1810) caught in the Western and Central Atlantic. PLoS ONE 11(4): e0153062. https://doi. org/10.1371/journal.pone.0153062

Baum, J. K., Myers, R. A., Kehler, D. G., Worm, B., Harley, S. J. and Doherty, P. A. 2003. Collapse and conservation of shark populations in Northwest Atlantic. Science, 299: 389-392. https://doi.org/10.1126/science.1079777

Beck, M.W., Heck, K. L., Able, K. W. Childers, D. L., Eggleston, D. B., Gillanders, B. M., Halpern, B., Hays, C. G., Hoshino, K., Minello, T. J., Orth, R. J., Serdan, P. F. and Weinstein, M. P. 2001. The Identification, conservation, and management of estuarine and marine nurseries for fish and invertebrates. BioScience, 51: 633-641. https://doi. org/10.1641/0006-3568(2001)051[0633:TICAMO]2.0.CO;2 
Cailliet G. M, Martin L. K., Harvey, J. T., Kusher, D. and Welden, B. A. 1983. Preliminary studies on the age and growth of the blue shark, Prionace glauca, common thresher, Alopias vulpinus, and shortfin mako, Isurus oxyrinchus, from California waters. US Department of Communication, NOAA Technical Reports, NMFS 8: 179-188.

Carey, F. G., and Teal, J. M. 1969. Mako and porbeagle: warm-bodied sharks. Comparative Biochemistry and Physiology, 28(1), 199-204. https://doi.org/10.1016/0010406X(69)91335-8

Casey, J. G. and Kohler, N. E. 1992. Tagging studies on the shortfin mako shark (Isurus oxyrinchus) in the western North Atlantic. Australian Journal of Marine and Freshwater Research, 43: 45-60. https://doi.org/10.1071/ MF9920045

Compagno, L. J. V. 1984. FAO species catalogue: sharks of the World: an annotated and illustrated catalogue of shark species known to date. FAO Fisheries Synopsis, 4(1-2): $665 \mathrm{p}$.

Compagno, L. J. V. 1990. Alternative life history styles of cartilaginous fishes in time and space. Environmental Biology of Fishes, 28: 33-75. https://doi.org/10.1007/97894-009-2065-1_3

Compagno, L. J. V. 2005. Checklist of living Chondrichthyes. In: W. Hamlett (Ed.), Reproductive Biology and Phylogeny of Chondrichthyes: Sharks, Batoids and Chimaeras, pp. 503-548. Science Publishers, Inc., Enfield, New Hampshire, USA.

Conde-Moreno, M., and Galván-Magaña, F. 2006. Reproductive biology of the mako shark Isurus oxyrinchus on the southwestern coast of Baja California, Mexico. Cybium, 30(4): 75-83.

Cortés, E., Arocha, F., Beerkircher, L., Carvalho F., Domingo, A., Heupel, M., Holtzhausen, H., Santos, M.N., Ribera, M., Simpfendorfer, C. 2010. Ecological Risk Assessment of Pelagic Sharks Caught In Atlantic Pelagic Longline Fisheries. Aquatic Living Resources, 23: 25-34. https://doi. org/10.1051/alr/2009044

Costa, F. E. S., Braga, F. M. S., Arfelli, C. A., and Amorim, A. F. 2002. Aspects of the reproductive biology of the Shortfin mako, Isurus oxyrinchus (elasmobranchii Lamnidae), in the southeastern region of Brazil. Brazilian Journal of Biology, 62(2): 239-248. https://doi.org/10.1590/S151969842002000200007

Francis, M. P., and Duffy, C. 2005. Length at maturity in three pelagic sharks (Lamna nasus, Isurus oxyrinchus, and Prionace glauca) from New Zealand. Fishery Bulletin, 103(3): 489-500.

Garcia, C. E. 1997. Physical oceanography. In: U. Seeliger, C. Odebrecht, and J. P. Castello (Eds.), Subtropical convergence environments. pp 94-96. The coast and sea in the southwestern Atlantic. Springer, Berlin Heidelberg New York.

Gilmore, R. G. 1993. Reproductive biology of Lamnoid sharks. In: L. S. Demski and J. P. Wourms, (Eds.), The reproduction and development of sharks, skates, rays and ratfishes. Environmental Biology of Fishes, 38(1-3): 95-114. https:// doi.org/10.1007/BF00842907
Gilmore, R. G. 2005. Oophagy, intrauterine canibalism and reproduction strategy in Lamnoid Sharks. In W. Hamlett, (Ed.), Reproductive Biology and Phylogeny of Chondrichthyes: sharks, batoids and chimaeras. pp 435-462. Science Publishers, Inc., Enfield, New Hampshire, USA.

Hamlett, W. C. and Koob, T. J. 1999. Female reproductive system. In: W. Hamlett, (Ed.), Sharks, Skates, and Rays. The Biology of Elasmobranch Fishes. pp. 398-443. Baltimore, MD. The John Hopkins University Press.

Holden, M. J. 1974. Problems in the rational exploitation of elasmobranch populations and some suggested solutions. In: F. R. Harden-Jones (Ed.) Sea fisheries research. pp. 117-137. John Wiley and Sons, New York.

Joung, S., and Hsu, H. 2005. Reproduction and embryonic development of the shortfin mako, Isurus oxyrinchus Rafinesque, 1810, in the Northwestern Pacific Zoology Studies, 44(4): 487-496.

Maia, A., Queiroz, N., Cabral, H. N., Santos, A. M., and Correia, J. P. 2007. Reproductive biology and population dynamics of the shortfin mako, Isurus oxyrinchus Rafinesque, 1810, off the southwest Portuguese coast, eastern North Atlantic. Journal of Applied Ichthyology, 23: 246-251 https://doi.org/10.1111/j.1439-0426.2007.00849.x

Mollet, H. F., Cliff, G., Pratt Jr. H. L., and Stevens, J. D. 2000. Reproductive biology of the female shortfin mako, Isurus oxyrinchus Rafinesque, 1810, with comments on the embryonic development of lamnoids. Fishery Bulletin, 98: 299-318.

Mollet, H. F., Testi, A.D., Compagno, L. J. V. and Francis, M. P. 2002. Re-identification of a lamnid shark embryo. Fishery Bulletin, 100: 865-875.

Mourato, B. L., Arfelli, C. A., Amorim, A. F., Hazin, H. G., Carvalho, F. C., and Hazin, F. H. V. 2011. Spatio-temporal distribution and target species in a longline fishery off the Southeastern Coast of Brazil. Brazilian Journal of Oceanography, 59(2):185-194. https://doi.org/10.1590/ $\underline{\text { S1679-87592011000200007 }}$

Pratt H. L. Jr., and Casey J. G. 1983. Age and growth of the shortfin mako, Isurus oxyrinchus, using four methods. Canadian Journal of Fisheries and Aquatic Science, 40: 1944-957. https://doi.org/10.1139/f83-224

R Core Team (2019). R: A language and environment for statistical computing. R Foundation for Statistical Computing, Vienna, Austria. URL: https://www.R-project.org/.

Rigby, C. L., Barreto, R., Carlson, J., Fernando, D., Fordham, S., Francis, M. P., Jabado, R. W., Liu, K. M., Marshall, A., Pacoureau, N., Romanov, E., Sherley, R. B. and Winker, H. 2019. Isurus oxyrinchus. The IUCN Red List of Threatened Species 2019: e.T39341A2903170. https://dx.doi. org/10.2305/IUCN.UK.2019-1.RLTS.T39341A2903170. en. Downloaded on 20 October 2020.

Schrey, A.W. and Heist, E. J. 2003. Microsatellite analysis of population structure in the shortfin mako (Isurus oxyrinchus) Canadian Journal of Fisheries Science, 60: 67-675 https://doi.org/10.1139/f03-064

Semba, Y., Ichiro, A., and Kotaro, Y. 2011. Size at maturity and reproductive traits of shortfin mako, Isurus oxyrinchus, in the Western and Central North Pacific. Marine and 
Freshwater Research, 62: 20-29 https://doi.org/10.1071/ MF10123

Stevens, J. D. 1983. Observations on reproduction in the shortfin mako Isurus oxyrinchus. Copeia: 126-130. https://doi. org/10.2307/1444706

Stevens, J. D. 2008. The Biology and Ecology of the shortfin mako shark, Isurus oxyrinchus. In: M. D. Camhi, E. K. Pikitch and E. A. Babcock (Eds.), Sharks of the Open Ocean: Biology, Fisheries and Conservation. pp 260-267. Blackwell, Oxford. https://doi.org/10.2307/1444706

Tsai, W., Liu, K., Punt, A. E. and Sun, C. 2014. Assessing the potential biases of ignoring sexual dimorphism and mating mechanism in using a single-sex demographic model: the shortfin mako shark as a case study. ICES Journal of Marine Science, 72(3): 793-803. https://doi.org/10.1093/ icesjms/fsu210

Vooren, C. M., Klippel, S., and Galina, A. B. 2005. Elasmobrânquios das águas costeiras da Plataforma Sul. In: C. M. Vooren and S. Klippel (Eds.), Ações para a conservação de tubarões e raias no sul do Brasil. pp. 113-120. Porto Alegre: Igaré.

Wyffels, J. T. 2009. Embryonic development of chondrichthyan fishes: a review. In: Y. Kunz, B. G. Kapoor, and C. A. Lauer (Eds.), Development of Non-Teleost Fishes. pp. 1-103. Science Publishers Inc., Enfield. https://doi.org/10.1201/ b10184-2 